\title{
Impact of Liquidity on Profitability: A Study on the Commercial Banks in Bangladesh
}

\author{
Sujan Chandra Paul ${ }^{1}$, Probir Kumar Bhowmik ${ }^{1,2}$ \\ and Mehbuba Nayan Famanna ${ }^{3}$
}

\begin{abstract}
This research aims to investigate the effect of banks' liquidity on its profitability; with the ordinary course of business and in the medium term (10 years).

A quantitative analysis is performed on a statistical sample of forty (40) commercial banks in Bangladesh. Secondary data is used to evaluate the performance of the last ten years (2009-2018) of the annual report of the commercial banks in Bangladesh with 206 bank years of data gathered to consider all Bangladeshi commercial banks. Proposed variables are: LDR, DAR, CDR, LAR and CR as liquidity representation; on the other hand, ROE is the profitability representation. Five hypotheses have been established to assess the effect of liquidity on profitability. Following a correlation and regression analysis, it is observed that LDR, DAR and CDR had a substantial effect on the profitability measured as ROE, but LAR and CR proved insignificant. Therefore, it can be concluded that, in general, the impact of liquidity has a significant effect on the profitability in the commercial banking sector of Bangladesh. By relying on this report; Bangladeshi banks will be best positioned to keep equality between its liquidity and profitability.
\end{abstract}

Keywords: Liquidity, Profitability, ROE, Commercial Banks.

\footnotetext{
${ }^{1}$ Department of Accounting and Information Systems, University of Barishal, Barishal.

*Corresponding author.

${ }^{2}$ School of Management, Huazhong University of Science and Technology, Wuhan, China.

${ }^{3}$ Independent Researcher, Department of Accounting and Information Systems, University of

Barishal, Barishal.
}

Article Info: Received: January 18, 2021. Revised: February 10, 2021.

Published online: February 15, 2021. 


\section{Introduction}

To ensure extensive multinational business activities around the globe, regardless of its scale, it participates in financial management and makes use of financial accounting techniques to be a profitable company. The primary objective of any company is to maximize its level of profitability[1].One of the oldest and most important activities is that companies prosper from profit maximization. Most market models that participate in the procurement of products or services proceed with profit maximization[2]. A company's income should be maximized and that most possibly successful transactions are made to achieve productivity in the managing of capital. Moreover, all decisions pertaining to acquisitions and funding and dividends are produced to maximize income. So, there exists a linear relationship between profitability and the vital organizational judgments that are subsequently created. This research would examine the effect of liquidity management decisions on the profitability of banks. The financial conditions that have arisen around the world in 2008 have demonstrated the degree to which liquidity will play a significant role in banks' operations, and this effect is not precisely on the banks' activities. Still, on banking performance, there exists a direct influence[3].

The definition of accounting liquidity is explained as "the ability of an organization to pay off matured short-term obligation within or less than one year." That is very much essential for the continued operation of the organization. When the liquidity ratio is greater than 1 it seems natural for a company when it is smaller than 1 it considers that the firms do not have enough capital to pay off short-term liabilities[4]. Usually, a high liquidity ratio is an indication of strong financial strength[5], Still, some analyses indicate that too high a liquidity ratio often expresses the organization's mismanagement concerns, which indicates that companies have not made the optimal use of assets for profit maximization due to reduced profitability of existing assets compared to fixed assets. The proper balance is not to have excess or inadequate liquidity consistent with the optimal operating ratio of the bank. Obtaining a rational trade-off between banks' liquidity and its profitability is the critical problem for liquid asset management. In comparison, a decrease of liquidity by a rise of working capital will result in a reduced rate of profitability if it could be spent[6]. Banks are also faced with liquidity control dilemmas. For example, whether to select investment in profit-generating activities, which are heavy-yield bonds that can't be volatile but offer greater returns, or yet to retain liquid asset by maintaining investment funds secure as liquid capital. Liquid money taken by the banks could lead to an opportunity cost or could end up as the basis for a big benefit maximization by the resilience it offers. The purpose of this analysis is to show how banks' liquidity and profitability are associated in the ordinary course of business. 


\subsection{Objectives}

The objective of this research is:

- Analyze the relationship between liquidity and profitability in the commercial banking sector in Bangladesh.

The study question is:

- "What is the impact of liquidity on profitability in the banking sector?

\section{Literature Review}

Prior studies have an essential role to play in the conduct of any form of study. In this way, by following the recommendations for such experiments, researchers will make their research more worthwhile. Some studies that are connected to this research are listed below:

The performance of the Nigerian bank during the period 2004 to 2012 is assessed by[7]. It evaluated the liquidity effect by using a generic method of timing. The outcome reveals exists a strong link between the level of liquid assets retained an banks' performance in Nigeria. They signal that banks should boost their liquidity to sustain advanced output.

Interaction between profitability and liquidity on behalf of Pakistani commercial banks between 2008 and 2014 is being investigated by[8].The bank's statistical data for the past five years has been used as secondary data usage. The gross profit margin and net profit margin ratios were supposed to be the indicator of profitability and the current ratio and the quick ratios were supposed to be the measure of liquidity. The mathematical study showed a strong positive association between liquid assets and the bank's profitability. It is also revealed that banks should have retained a significant amount of their net assets to increase profitability.

The same opinion that bank liquidity has a major effect on the banks' profitability is clarified by[9]. Secondary data were used in this analysis, which was taken from the annual reports of 8 different banks between 2004 and 2015. The regression analysis and correlation methods were used in this research. Current Ratio (CR) and Cash Ratio (CASR) were used as liquidity substitutes as an independent variable, whereas Return on Assets (ROA) was used to assess profitability as a dependent variable. The analysis concluded that there exists an important link between the liquid assets and the banks' profitability.

The partnership between Nigerian banks' liquidity management and efficiency is being investigated by[10]. Which discussed the need for more reliable and productive liquidity management in order to sustain and effectively run banks. The usual least square approach was used there and concluded a substantial correlation between liquidity and performance measures.

An analysis to create a liquidity management effect on commercial banks' performance measures as profitability is conductedby[11]in Jordan. This analysis considers liquidity as an independent representative whereas return on assets (ROA) and return on equity (ROE) as a contingent variable to calculate the profitability of 
the bank. Financial data is analyzed using mathematical methods and a ratio analysis. The study concluded that expenditure and rapid ratio $(\mathrm{QR})$ are positively associated with profitability when calculated by (ROE). Again, the effect of the capital ratio was positive when calculated by (ROA).

Financial data is analyzed using mathematical methods and ratio analysis. The study concluded that the expenditure and quick ratio $(\mathrm{QR})$ effect is positively associated with the profitability when calculated by (ROE). Once again, the impact of the capital ratio was positive when calculated by (ROA). The other independent variables had a little positive effect on the two profitability indicators (ROA) and (ROE). The researcher thus recommended that there is a need to draw on the liquidity of the banks.

The link of liquidity with its profitability between 2006 and 2011 for the banking sector in Bangladeshis investigated by[12]. But there was no significant relationship between liquidity and profitability in this industry (government bank, Islamic bank, private commercial bank, and multinational bank). Only two vector liquidity (current ratio) and profitability (ROA) are used, so their estimates suffer from excluded variable bias.

The same view is also disclosed by[13] which indicate that there exist no substantial association between banks' liquidity and profitability representing a sample of twelve banks in Bangladesh. There (ROA) represents an independent variable and the current ratio (CR) represents an independent variable.

On the other hand, a favorable association between return on assets(ROA) and liquid assets(cash and bank balances) with limited liabilities and return on equity ( ROE) and cash and bank balances with total liabilities is found by[14]. They analyzed the effect of liquidity on Nigerian banks' profitability from 2003 to 2012 . They also found that no substantial effect has existed between the liquidity and profitability among the in Nigeria. Its liquidity has impaired the profitability of commercial banks is reported by[15].There exist a negative correlation between the liquidity and performance of the banks and vice versa. The data from this analysis was obtained mainly from the selected banks' management and financial statements and analyzed using the Pearson correlation methodology.

\section{Research Design and Methodology}

\subsection{Quantitative Data Procurement}

Quantitative analysis is the right research design for the essence of the sample. Secondary data obtained from reported annual reports by commercial banks in Bangladesh. Yearly data compiled on the website of individual banks.

To drive this research objectives, a sample of forty (40) commercial banks are the representative sample of the total 62 schedule banks in Bangladesh. Only focusing on the banking industry this study is made up. Moreover, a time frame of ten (10) years from 2009 to 2018 is calculated for this analysis which can be supposed that, this samples will adopt a conclusion that can be generalized. 
Table 1: Sample size

\begin{tabular}{|l|l|}
\hline Number of commercial banks available from 2009 to $2018(40 * 10)$ & $\mathbf{4 0 0}$ \\
\hline Less : Non-availability of annual reports and data & $\mathbf{1 9 4}$ \\
\hline Total banking firm year of observations & $\mathbf{2 0 6}$ \\
\hline
\end{tabular}

Table 2:Independent and dependent variables

\begin{tabular}{|l|l|}
\hline Independent variables (liquidity representatives) & $\begin{array}{c}\text { Dependent variables } \\
\text { (profitability representatives) }\end{array}$ \\
\hline Loan to Deposit Ratio (LDR) & \multirow{2}{*}{ Return on Equity (ROE). } \\
\cline { 1 - 1 } Deposit to Assets Ratio(DAR) & \\
\cline { 1 - 1 } Cash and Cash Equivalents to Deposit Ratio (CDR) & \\
\cline { 1 - 1 } Liquid Assets Ratio (LAR) and & \\
\hline Current Ratio (CR) &
\end{tabular}

Those variables are calculated through formulas develop by authors over a mid-long range time period of 10-yearswhich are listed below:

Table 3:Formulas of the ratios

\begin{tabular}{|ll|l|}
\hline \multicolumn{1}{|c|}{ Variables } & \multicolumn{1}{c|}{ Formula } \\
\hline 1. & Loan to Deposit Ratio (LDR) & Loan \& Advance / Total Deposits \\
\hline 2. & Deposit to Assets Ratio (DAR) & Total Deposits / Total Assets \\
\hline $\begin{array}{l}\text { 3. } \\
\text { Cash and Cash Equivalents to } \\
\text { Deposit Ratio (CDR) }\end{array}$ & Cash and Cash Equivalents / Total Deposits \\
\hline 4. & Liquid Assets Ratio (LAR) & Cash and Cash Equivalents / Current liabilities \\
\hline 5. Current Ratio (CR) & Current Assets / Current Liability \\
\hline 6. & Return on Equity (ROE) & Net Income / Shareholders' Equity \\
\hline
\end{tabular}

\subsection{Quantitative Data Analysis}

After investigating data collected from published annual reports and testing assumed hypotheses, statistical analysis are used. For exploring data, Statistical Package for Social Sciences (SPSS) is used. Through SPSS, here compute descriptive statistics, correlation and also run regression model, analyze model summary, ANOVA, and coefficient value. The ANOVA analysis techniques are used to examine the study hypothesis. Analysis of descriptive statistics and correlations coefficient is presented prior to the main analysis. After that multiple regression analysis model is used. The key objective of these analyses is to determine the effects of banks' liquidity on the performance of the banks measured as profitability.

\subsection{Descriptive Statistics}

SPSS software version 16.0 is used here to give more understanding relating to the 
similar study variables that were being analyzed before. The statistical analysis formed descriptive statistics before another test accomplished using correlation and regression analysis. That descriptive statistics produces the mean and standard deviation for each variable.

\subsection{Correlation Test Regression Analysis}

After descriptive statistics, the correlation test regression analysis arrives prior to the start of regression analysis. The correlation coefficient was used to examine the link between dependent and independent representatives. Pearson correlations coefficients are tested for determining the level of the relationship exist between dependent and independent representatives.

\subsection{Multiple Regression Analysis}

To evaluate the objectives of this research which is to examine the impact of the liquidity on banks profitability, here is used multiple regression analysis for investigating the causal effects of the independent representatives such as (LDR, DAR, CDR, LAR and CR) with the dependent representative that is measured as (ROE). When the coefficient significance level is lower than the significant level) it is implausible that the coefficient occurred fortuitously, and when the significance value exists above the significant level it states the vice-versa[16], here in this study $\alpha=0.05$.

The multiple regression model is given below:

$\mathrm{Y}=\alpha+\beta 1 \mathrm{LDR}+\beta 2 \mathrm{DAR}+\beta 3 \mathrm{CDR}+\beta 4 \mathrm{LAR}+\beta 5 \mathrm{CR}+\varepsilon$

Here:

$\mathrm{Y}=$ Dependent Variable,

$\alpha=$ Constant,

$\beta=$ Regression Coefficient,

$\varepsilon=$ Error term

After conducting the model of data for the commercial banks, this is supposed that it would be possible to examine the effects of banks' liquidity on the profitability in the commercial banking sector depending on the selected representatives.

\subsection{Conceptual Framework and Hypothesis Development}

In order to supervise the durability of the financial condition of any organization liquidity is often viewed as shrewd monitoring measure. The continuous regulations from government to increase liquidity drive to keep up sustainable development of the banks. On the other hand, in order to achieve wealth maximization, profitability is the major reasonable factor for which the shareholders and managers think about utmost. As the measurement of liquidity conducted by previous research was excluded from the general determinants of the bank's profitability, investigating the 
relationship between liquidity and profitability was not enough in previous research. Because of the global financial crisis happened in 2008, it made financial analyst acknowledge the significance of liquidity management and the equality between liquidity and profitability of the banks. Here used the conceptual model to inspect the link between liquidity and profitability of the commercial banking sectors of Bangladesh to examine the quantitative part of this study.

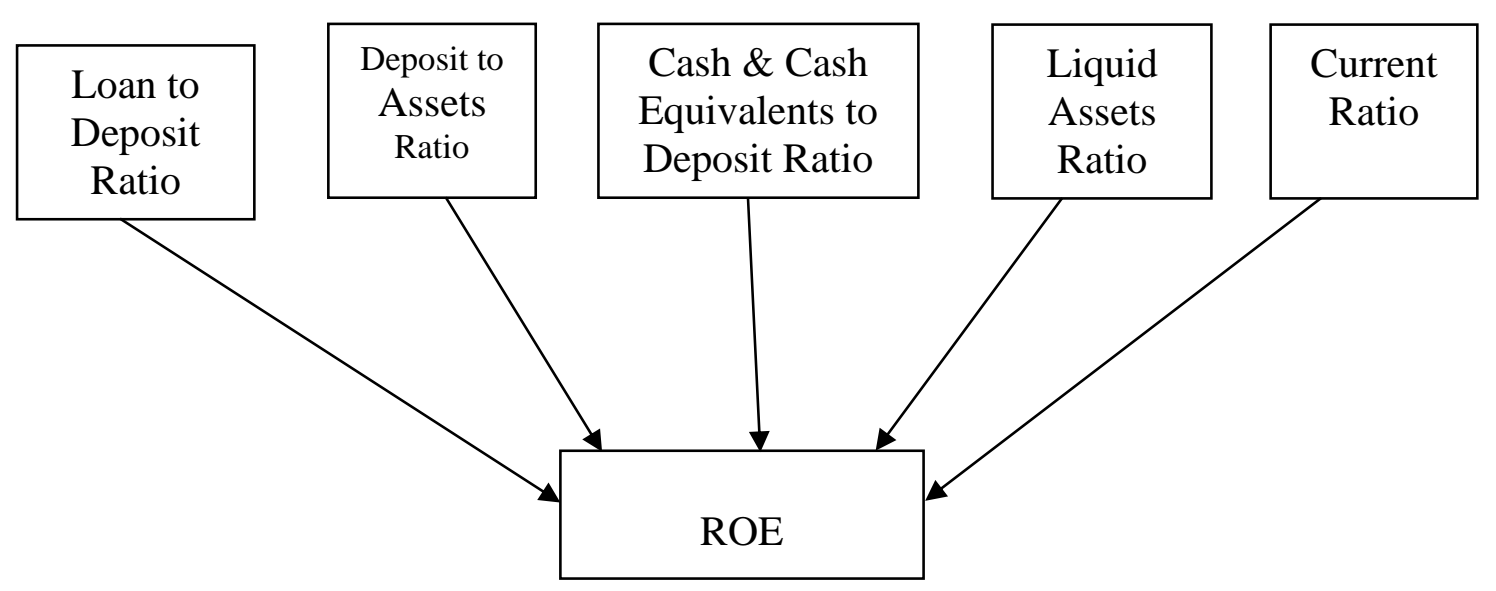

Figure 1: Conceptual model

Table 4: Proposed hypotheses

\begin{tabular}{|l|l|}
\hline & \multicolumn{1}{|c|}{ Hypotheses } \\
\hline H1 & The Loan to Deposit Ratio (LDR) has a significant impact on ROE. \\
\hline H2 & The Deposit to Assets Ratio(DAR) has a significant impact on ROE. \\
\hline H3 & The Cash \& Cash Equivalents to Deposit Ratio (CDR) has a significant impact on ROE. \\
\hline H4 & The Liquid Assets Ratio (LAR)has a significant impact on ROE. \\
\hline H5 & The Current Ratio(CR) has a significant impact on the ROE. \\
\hline
\end{tabular}

\section{Results and Discussion}

\subsection{Descriptive Statistics}

Investigation of the data accumulated through certain values, its central tendency, its range, divergence around the mean is very necessary prior to examination of sophisticated analyses. Hence, the descriptive statistics are conducted which is namely ROE, LDR, DAR, CDR, LAR \& CR. To uphold the understanding relating to the constructs here determined their range, minimum, maximum, mean value, standard deviation, and variance. 
Table 5: Descriptive statistics

\begin{tabular}{|l|c|c|c|c|c|c|c|}
\hline & $\mathbf{N}$ & Range & Minimum & Maximum & Mean & $\begin{array}{c}\text { Std. } \\
\text { Deviation }\end{array}$ & Variance \\
\hline ROE & 206 & 53.69 & .06 & 53.75 & 15.4246 & 9.40116 & 88.382 \\
\hline LDR & 206 & 74.16 & 24.10 & 98.26 & 79.9542 & 11.11407 & 123.523 \\
\hline DAR & 206 & 94.82 & 1.01 & 95.83 & 76.2552 & 12.33197 & 152.078 \\
\hline CDR & 206 & 78.39 & .61 & 79.00 & 11.4970 & 14.32628 & 205.242 \\
\hline LAR & 206 & 28.61 & 1.00 & 29.61 & 9.0450 & 3.64582 & 13.292 \\
\hline CR & 206 & 2.76 & .42 & 3.18 & 1.1803 & .30867 & .095 \\
\hline $\begin{array}{l}\text { Valid N } \\
\text { (list wise) }\end{array}$ & 206 & & & & & & \\
\hline
\end{tabular}

This values of the above set up from each single banks and time period of mid-long range of ten years.

\subsubsection{Mean}

The Mean value of ROE is $15.42 \%$ which shows a good picture of banks performance on average. A general ROE in any distinct sector could be nearly $10 \%$ or less than usual. The rate for technology or retail firm and lesser financial transactions comparative to net income may be more than or equal to $18 \%$ of the ROE level. It is better to target an ROE equivalent to or to some more than the average for the respective groups. Accordingly, the mean of both LDR and DAR was quite closure which are 79.95 and 76.25. The mean LDR shows that on average there are $79.95 \%$ of deposit are given as loan by both conventional banks and shariah-compliant Islamic banks. Bangladesh Bank set a regulation to fix the ratio of $83.5 \%$ for conventional banks and IDR as $89 \%$ for shariah-compliant Islamic banks. The DAR mean is $76.25 \%$ which indicate that commercial banks on an average financed their assets nearly $76.25 \%$ of deposits through the mid-long range periods of ten years. The CDR states the level of liquidity a bank have to carrying its accounting relating to the depositors' amount it maintains. The CDR mean is $11.50 \%$ shows that banks hold as much as $11.50 \%$ cash and cash equivalent as liquid assets compared to total deposit. The LAR (liquid asset ratio) indicates a liquidity dimension of an organization's ability to pay off its short-term liabilities through cash and cash equivalents. An organization's total reserve of cash and near-cash securities is divided by its total current liabilities for achieving liquid asset ratio. Here the mean of LAR is $9.05 \%$.The mean CR (current ratio) 1.18 indicates a ratio of an organization's current assets to its total current liabilities. This ratio is generally defined as an assets an asset that can be turned into cash within a year or less, and liabilities can be paid off within a year or less. 


\subsubsection{Standard Deviation}

Dispersion of data through the mean is calculated by the standard deviation measures[17]. It is assumed that the dataset is normally distributed; the LDR standard deviation of $11.11 \%$ which is about seven times smaller. The DAR standard deviation representing $12.33 \%$ which is approximately six times smaller than the actual mean value. The standard deviation of CDR is nearly 14.33 that is higher than for a mean value of 11.50 and indicates the extreme variation in CDR of the commercial banks. On the other hand, the standard deviation for the ratio LAR and $\mathrm{CR}$ are 3.65 and 0.31 consecutively. The significant differences reveal that most commercial banks are idiosyncratic to one another under several set of obligations, several market situations through some other regulations. The standard deviation of ROE is 9.40, which is also so high compare to the mean value of 15.42 .

\subsection{Correlations}

The correlation coefficient's value always ranges between -1.0 which indicates a strong negative correlation and +1.0 which indicates a strong positive correlation. The values range nearly or close to zero indicates weak or no linear relationship. The linear correlations among the independent representatives of LDR, DAR, CDR, LAR and CR and dependent representative that is measured as (ROE) are given below:

Table 6: Pearson's correlation

\begin{tabular}{|c|c|c|c|c|c|c|c|}
\hline & & ROE & $L D R$ & $\overline{D A R}$ & $C D R$ & $L A R$ & $C R$ \\
\hline$R O E$ & $\begin{array}{l}\text { PC*** } \\
\text { Sig.( 2-tailed) }\end{array}$ & 1 & & & & & \\
\hline$L D R$ & $\begin{array}{l}\text { PC } \\
\text { Sig. (2-tailed) }\end{array}$ & $\begin{array}{l}.450^{* * *} \\
.000\end{array}$ & 1 & & & & \\
\hline$D A R$ & $\begin{array}{l}\text { PC } \\
\text { Sig.( 2-tailed) }\end{array}$ & $\begin{array}{l}.365^{* *} \\
.000\end{array}$ & $\begin{array}{l}.291 * * \\
.000\end{array}$ & 1 & & & \\
\hline$C D R$ & $\begin{array}{l}\text { PC } \\
\text { Sig.( 2-tailed) }\end{array}$ & $\begin{array}{l}-.003 \\
.965\end{array}$ & $\begin{array}{l}-.339 * * \\
.000\end{array}$ & $\begin{array}{l}-.135 \\
.053\end{array}$ & 1 & & \\
\hline$L A R$ & $\begin{array}{l}\text { PC } \\
\text { Sig. (2-tailed) }\end{array}$ & $\begin{array}{l}.153^{*} \\
.028\end{array}$ & $\begin{array}{l}.117 \\
.094\end{array}$ & $\begin{array}{l}.043 \\
.539\end{array}$ & $\begin{array}{l}.037 \\
.597\end{array}$ & 1 & \\
\hline$C R$ & $\begin{array}{l}\text { PC } \\
\text { Sig. (2-tailed) }\end{array}$ & $\begin{array}{l}-.039 \\
.581\end{array}$ & $\begin{array}{l}-.182 * * \\
.009\end{array}$ & $\begin{array}{l}-.184 * * \\
.008\end{array}$ & $\begin{array}{l}.035 \\
.619\end{array}$ & $\begin{array}{l}.046 \\
.515\end{array}$ & 1 \\
\hline
\end{tabular}

$* * *(\mathrm{PC})=$ Pearson Correlation

** Significant correlation at the 0.01 level (2-tailed).

*Significant correlation at the 0.05 level (2-tailed). 


\subsection{Regression Analysis: ROE and Liquidity Proxies}

Regression analysis was carried out for investigating the effects of liquidity on banks profitability. This analysis is based on return on equity(ROE) as the dependent representative whereas LDR, DAR, CDR, LAR and CR were acted as independent representatives.

Table 7: Model summary

\begin{tabular}{|c|c|c|c|c|}
\hline Model & $\mathrm{R}$ & R Square & $\begin{array}{c}\text { Adjusted R } \\
\text { Square }\end{array}$ & $\begin{array}{c}\text { Std. Error of } \\
\text { the Estimate }\end{array}$ \\
\hline $\mathbf{1}$ & $\mathbf{. 5 5 1 a}$ & $\mathbf{. 3 0 4}$ & $\mathbf{. 2 8 7}$ & $\mathbf{7 . 9 4 0 5 3}$ \\
\hline \multicolumn{2}{|l}{ a. Predictors: (Constant), LDR, DAR, CDR, LAR and CR } \\
\hline
\end{tabular}

Here, R-squared's value is 0.304 which expresses that about $30.4 \%$ discrepancies in explain by the independent variables(LDR, DAR, CDR, LAR and CR) in the model. In this model summary, the adjusted $\mathrm{R}$ square is $28.7 \%$, indicating that $28.7 \%$ of the variation of return on equity (ROE) is caused by independent representatives (LDR, DAR, CDR, LAR and CR).

Table 8: ANOVA b

\begin{tabular}{|c|c|c|c|c|c|}
\hline Model & $\begin{array}{c}\text { Sum of } \\
\text { squares }\end{array}$ & df & $\begin{array}{c}\text { Mean } \\
\text { square }\end{array}$ & F & Sig. \\
\hline Regression & $\mathbf{5 5 0 7 . 8 6 6}$ & $\mathbf{5}$ & $\mathbf{1 1 0 1 . 5 7 3}$ & $\mathbf{1 7 . 4 7 1}$ & $\mathbf{. 0 0 0 a}$ \\
\hline Residual & $\mathbf{1 2 6 1 0 . 3 9 6}$ & $\mathbf{2 0 0}$ & $\mathbf{6 3 . 0 5 2}$ & & \\
\hline Total & $\mathbf{1 8 1 1 8 . 2 6 2}$ & $\mathbf{2 0 5}$ & & & \\
\hline \\
a. Predictors: (Constant), CR, CDR, LR, DAR, LDR \\
\hline
\end{tabular}

ANOVA test is essential in constructing whether the judgments would have been derived through a sampling error. If the regression line differs from zero, the ANOVA test also helps to conclude. When the regression line varies from 0(zero), it indicates that there is no sampling error which can affect the findings.

It can be seen from ANOVA table that, at $95 \%$ confidence level and at 0.05 of significance level, the model is significant as the value of F, which is 17.471 is greater than the Sig. Value. 
Table 9: Regression coefficients

\begin{tabular}{|c|c|c|c|c|c|}
\hline \multirow[t]{2}{*}{ Model } & \multicolumn{2}{|c|}{$\begin{array}{c}\text { Unstandardized } \\
\text { coefficients }\end{array}$} & \multirow{2}{*}{\begin{tabular}{|c|}
$\begin{array}{c}\text { Standardized } \\
\text { coefficients }\end{array}$ \\
Beta \\
\end{tabular}} & \multirow[t]{2}{*}{$\mathbf{t}$} & \multirow[t]{2}{*}{ Sig } \\
\hline & B & Std. Error & & & \\
\hline (Constant) & -36.011 & 6.101 & & -5.903 & .000 \\
\hline LDR & .368 & .056 & .435 & 6.567 & .000 \\
\hline DAR & .208 & .048 & .273 & 4.383 & .000 \\
\hline CDR & .115 & .041 & .175 & 2.785 & .006 \\
\hline LAR & .207 & .154 & .080 & 1.343 & .181 \\
\hline CR & 2.473 & 1.852 & .081 & 1.335 & .183 \\
\hline
\end{tabular}

The regression model coefficients shall show the regression coefficients and the intercept and the importance of the standardized and unstandardized coefficients. The standardized beta coefficient determined the unit change in the standard deviation of the return on equity (ROE) for each unit change in the standard deviation of the independent representatives, DAR, CDR, LAR and CR. This shows that with each unit shift from LDR, DAR, CDR, LAR and CR standard deviation, ROE would shift by $43.50 \%, 27.30 \%, 17.50 \%, 8.00 \%$ and $8.10 \%$ respectively.

The confidence level is $95 \%$, the meaning norm is a p-value that is less than 0.05 . It can also be inferred that RAO-dependent LDR, DAR and CDR have a substantial effect on profitability. The other two independent delegates (LAR and CR) have an insignificant influence as the Sig. The meaning of LAR and CDR is greater than 0.05 .

Table 10: Revised hypotheses

\begin{tabular}{|c|c|c|c|}
\hline Abbreviation & Hypotheses & Significance & Verdict \\
\hline H1 & $\begin{array}{l}\text { The LDR (Loan Deposit Ratio) has a } \\
\text { significant impact on the ROE }\end{array}$ & .000 & Supported \\
\hline $\mathbf{H 2}$ & $\begin{array}{l}\text { The DAR (Deposit Assets Ratio) has a } \\
\text { significant impact on the ROE }\end{array}$ & .000 & Supported \\
\hline H3 & $\begin{array}{l}\text { The CDR (Cash \& Cash equivalents to } \\
\text { Deposit Ratio) has a significant impact } \\
\text { on ROE }\end{array}$ & .006 & Supported \\
\hline H4 & $\begin{array}{l}\text { The LAR (Liquid Asset Ratio)has a } \\
\text { significant impact on the ROE }\end{array}$ & .181 & $\begin{array}{c}\text { Not } \\
\text { Supported }\end{array}$ \\
\hline H5 & $\begin{array}{l}\text { The CR (Current Ratio) has a } \\
\text { significant impact on the ROE }\end{array}$ & .183 & $\begin{array}{c}\text { Not } \\
\text { Supported }\end{array}$ \\
\hline
\end{tabular}

Determining the values of the coefficients of the research models

The regression model is given below: 
$\mathrm{Y}=\alpha+\beta 1 \mathrm{LDR}+\beta 2 \mathrm{DAR}+\beta 3 \mathrm{CDR}+\beta 4 \mathrm{LAR}+\beta 5 \mathrm{CR}+\varepsilon$

The regression equations will be written based on the values of the coefficients is given below:

$\mathrm{Y}=-5.903+6.567 \mathrm{LDR}+4.383 \mathrm{DAR}+2.785 \mathrm{CDR}+1.343 \mathrm{LAR}+1.335 \mathrm{CR}+\varepsilon$

The above equation states that the profitability of the banking industry is positively affected by the all proposed liquidity ratios as measured by return on equity (ROE).

\subsection{Hypotheses Analysis}

After testing the correlations and regression analysis by focusing on the model constructs where the independent variables are (LDR, DAR, CDR, LAR and CR) and the depended variable is the return on equity (ROE) where the main motive of this research is to investigate the effects of liquidity on profitability in the commercial banking sector of Bangladesh. Statistic analytical discussion is hold on to analyze the proposed hypotheses in order to present and evaluate the key research purpose.

H1: The loan to deposit ratio (LDR) has a significant impact on the return on equity (ROE)

The result of the first hypothesis shows that the regression analysis supports it. The loan to deposit ratio, which acts one of the independent variables is significant to the dependent variable as return on equity. Therefore, the study clearly shows that the hypothesis of loans to deposits ratio impacts return on equity (ROE) is accepted. This acceptance states that if a bank raises its loan level compared to its deposits, it will significantly impact its profitability. Hence, the linear correlation between loan to deposit ratio and return on equity has a positive relationship that indicates that if one is increasing, the other will also be increased and vice-versa.

This result indicates that the LDR ratio has statistical significance for profitability as measured by ROE. The possible reason is that when the level of loan is raised it would also be supposed to increase the level of interest revenue received by the bank[18]. Cause the interest revenue from loans offers a bank higher return to any other investment. This reduction in bank's deposits levels cause to lose the source of cheap funds which could be utilized the emergence liquidity need along with the cheaper source of investments. When any bank faces any liquidity crisis or has to meet the reserve requirements, it has to borrow generally from central bank or other commercial banks. In relating to the monetary policy decisions, the central bank usually has set the benchmark rate of these short-term loans taken by the bank to meet its fund crisis[19]. That benchmark rate sometimes has seen a unusual 
increment in the period of the financial emergence. Therefore bank has to pay severe interest rates to fulfil liquid assets demand[20]. Hence, the bank's cost of fund to meet liquidity demand would become higher than the interest revenue earned through giving loans, and that outcome shall be on a return calculated on the depositors funds and total average asset.

But here, the calculated average mean Loan Deposit Ratio is $79.95 \%$ for the banking sectors in Bangladesh which is below the declared LDR by Bangladesh Bank. ' 'That's why; here remain a positive correlation between loan to deposits ratio and return on equity.

$\mathrm{H} 2$ : The deposit to asset ratio has a significant impact on the return on equity

The result of the second hypothesis shows that it is supported by the regression analysis. It indicates that there exists a statistically significant relationship between the liquidity representatives of deposit assets ratio (DAR) to the profitability representative of return on equity (ROE). In consequence, here exist a medium positive linear correlation between deposit assets ratio and return on equity that indicates that those dependent and independent representatives supposed to move in the similar way. Hence, the deposits to assets ratios that a bank has to maintain have significant impact on its profitability as measured by ROE. As there exist a strong positive linear relationship which concluded that an increase in the level of deposits will also bring an output of an improvement of return on equity.

This outcome is a result of the bank's ability to invest in distinct financial portfolio where the rate of return is greater than the interest pain on the corresponding deposits. This situation has given an opportunity for commercial banks to earn more interest revenue on provided loans and other debt facilities that have spread out to other customers.

H3: The cash \& cash equivalents to deposit ratio has a significant impact on the return on equity

Through regression analysis, the third hypothesis is accepted. The cash $\&$ cash equivalents to deposit ratio which acts one of the independent variables is statistically significant in relation to the dependent variable as return on equity. Hence, the cash \& cash equivalents to deposits ratio significantly impact return on equity is supported by the regression analysis. The result indicates that the banks' performance is also supposed to have a significant impact if commercial banks raise their level of liquidity in relation to the enhancement of cash and cash equivalents.

H4: The liquid asset ratio has a significant impact on the return on equity

The result of the fourth hypothesis indicates that the regression analysis does not 
support it. The variable of the liquid assets ratio is insignificant in relation to the return on equity. Therefore, the study shows that the liquid asset's hypothesis to current liability ratio has no significant impact on the return on equity and so the proposed hypothesis is rejected. This indicates that if a bank raises its liquid assets ratio compared to its current liability, it can't affect its profitability. There is a positive linear relationship between liquid assets ratio and return on equity that results that if one variable is increasing, the other variables will also be increased and vice-versa and any emergence of inverse relationship has resulted from other factors the economy. The conclusion regarding liquid assets ratio is statistically insignificant as compared to ROE.

This study found that though LAR has a weak positive correlation with ROE but has no significant impact on ROE. This is possible because the mean average LAR is only $9.05 \%$. The reason for positive correlation might be that the individual investors find it save to have a liquid asset in the hand of banks though there exists no significant relationship between LAR and ROE.

H5: The current ratio has a significant impact on the return on equity

Through regression analysis, the result of the fifth hypothesis is not supported. The current ratio that acts one of the independent variables is statistically insignificant compared to the dependent variable as return on equity. The hypothesis that the current ratio has a significant impact on equity return is not selected based on the study data. Moreover, a weak negative linear correlation exists between current ratio and return on equity, indicating that when one variable moves in one direction the other will move in the opposite direction. The regression analysis conducted provided that with results where there is no significant relationship between ROE and $\mathrm{CR}$ and the correlation coefficient shows that there is a weak positive correlation between ROE and CR. The possible reason for the nonimpact on the profitability through current ratio is that different businesses have marked different rates for their standards ratio and that's why it can't lead to productive insight.

\section{Conclusion and Recommendations}

This analysis's key motive is to describe the effect of liquidity on profitability in Bangladesh's banking sector. In line with this, the general research issue was to assess the effect of liquidity on the banking sector's viability. Here, the research period is from 2009 to 2018 , which is the period since the 2008 global financial crisis, provided the focus on the liquidity and profitability trade-off of the banks. However, this study showed that, in that time period, banks had made investments in loans and other liquid assets in comparison to the need for banks to retain sound liquidity management. While there is no serious effect of the financial crisis in Bangladesh like every other major economy nation, the influence of the crisis has gradually decreased as financial markets and economies try to sustain tighter control. That's why the banks' profitability shows varying consequences for stricter 
supervision, battling with each other, and for the economic slowdown stemming from the economic meltdown. Banks have significant portfolios in government securities to mitigate their liquidity risks, which are also described in this study period.

\subsection{Recommendations}

Liquidity management is one of the bank's main goals as it has a larger impact on profitability. It may also be advised that banks spend their excess liquid volume, which stays idle after compliance with regulatory and consumer requirements. It is important for banks to invest in portfolios to benefit from the time value of the surplus capital available on their hands and become more profitable. To ensure sufficient liquidity, a general liquidity management system should be implemented by Bangladesh's commercial banks to carry out their work effectively. Commercial banks can use scientific methods to diagnose the strengths and limitations of the liquidity situation, especially in unexpected situations that banks could uncover, and banks can also carry out an observational analysis of the pace of liquidity development in order to determine the capacity of banks to manage sources and exercise funds.

Any guidelines are focused on the rigorous appraisal of the results of the report. It is hoped that these guidelines would help to mitigate the problems of liquidity management and profitability in Bangladesh's banking sector, although they are not entirely eradicated.

Commercial banks should not only rely on the principle of profit maximization but should also rely on steps to ensure effective liquidity control, considering the high importance of liquidity management in the profitability of banks. These interventions can aim to minimize or remove cases of excessive and insufficient liquidity as they have detrimental consequences.

Since the sustainability of commercial banks relies on liquidity control and profitability, and thus, instead of retaining unnecessary empty liquid volumes as a provision for unexpected withdrawal requirements from depositors, banks should find it viable to take the required steps to satisfy those sudden requirements ( e.g. short-term funding and bill discounting).

A consumer portal may be set up by commercial banks, where their clients/ depositors can hear about the various deposit conditions and the operating specifications of each of them. This method makes it easier for banks to measure the liquidity amount to be retained while customers run some of the deposits as needed.

\subsection{Practical Contributions}

This research study has practical significance, especially for the commercial banking sector in Bangladesh. To ensure sufficient liquidity, a general liquidity management system should be implemented by Bangladesh's commercial banks to carry out their work effectively. Efficient cash control may be a distinction between 
continuous operation and insolvency. In the run-up to the 2008 financial crisis, most banks stressed profitability above other new facets of their industries, e.g. liquidity management. This study shows that successful liquidity management activities impact profitability; hence, banks need not only rely on the principle of benefit maximization by compromising the current state of concern. Commercial banks may take advantage of this by striking the correct combination of liquidity and profitability.

\subsection{Suggestions for Further Research}

This research focuses on the goal of assessing the effect of liquidity on the profitability of banks. As a result, further analysis on liquidity control and viability remains feasible. It may become attractive if a further analysis is focused on concentrating on all smaller banking operations carried out by small banking organizations and for longer periods of time. It would also be attractive to expand this research to other industry segments based on a longer span of research in order to take into account more detailed causal impact of liquidity control on profitability. Finally, it will be best to carry out a related analysis using a qualitative or hybrid approach to clarify the connection between banks' level of liquidity and profitability. 


\section{References}

[1] Paramasivan, C. \& Subramanian, T. (2016). Financial Management. New Delhi: New Age Publishers.

[2] Levitt, S. (2016). Bagels and donuts for sale: A case study in profit maximization. Research in Economics, 70(4), 518-535.

[3] Lamberg, S. \&Valming, S. (2009). Impact of Liquidity Management on Profitability. ' 'Master's dissertation. Umeå: Umeå University.

[4] Morrel, P. S. (2007). Airline Finance. Burlington: Ashgate Publishing Company.

[5] Chandra, P. Financial Management. 7th edition. McGraw-Hill.

[6] Raykov, E. (2017). The liquidity-profitability trade-off in Bulgaria in terms of the changed financial management functions during crisis. Management: Journal of Contemporary Management Issues, 22(1), 135-156.

[7] Hakimi, A., \&Zaghdoudi, K. (2017). Liquidity Risk and Bank Performance: An Empirical Test for Tunisian Banks. Business and Economic Research, 7(1), 46-57.

[8] Khan, A., \&Mutahhar Ali, R. (2016). Impact of Liquidity on Profitability of Commercial Banks in Pakistan: An Analysis on Banking Sector in Pakistan.

[9] Maqsood, T., M. A. Anwer, A. Raza, M. Ijaz, and U. Shouqat. 2016. Impact of Liquidity Management on Profitability in Banking Sector of Pakistan. International review of management and business research 5 (2).

[10] Bassy, F. A., Tobi, E. G., Bassey, I. F., \&Ekwere, R. E. (2016). Liquidity Management and the Performance of Banks in Nigeria. International Journal of Academic Research in Accounting, Finance and Management Sciences, Vol. 6(No.1), 8. doi:10.6007/IJARAFMS/v6-i1/1955.

[11] Alshatti, A. S. (2015). The Effect of the Liquidity Management on Profitability in the Jordanian Commercial Banks. International Journal of Business and Management, 10(1), 62.

[12] Afia, A. Mahmud, K (2014). Liquidity-Profitability in Bangladesh Banking Industry. International Journal of Empirical Finance Vol.2, No. 4, 2014, 143151.

[13] Akter, A., Mahmud, K. (2014). Liquidity-Profitability Relationship in Bangladesh Banking Industry. International Journal of Empirical Finance. 2(4): 143-151.

[14] Junaidu M. K, Aminu, A (2014). An evaluation of the impact of liquidity on the profitability of Nigerian Banks. Research ' 'Journali's Journal of Management, Vol 2, No 7 August 2014.

[15] Olagunju, A., David, A. O., \& Samuel, O. O. (2011). Liquidity Management and Commercial Banks' Profitability in Nigeria. Research Journal of Finance and Accounting, 2(7), 2222-2847.

[16] Saunders, M.N., Lewis, P., \&Thornhill, A. (2009). Research methods for business students. 5th edition. Harlow: Pearson Education. 
[17] Cohen, L. Manion, L. \& Morrison, K. (2007). Research Methods in Education, Taylor \& Francis Group. 1993

[18] Ducy, M.\&Iqbal, Z. (2003). Effects of FHLB Advances on Commercial Bank Loans and Profitability in Texas. Bank Accounting \& Finance, 10/03 \#2.

[19] Elliott, D. (2014). Bank Liquidity Requirements: An Introduction and Overview. The Brookings Institution. https://www.brookings.edu [Retrieved:2018-05-03].

[20] Illes, A., Lombardi, M. \&Mizen, P. (2015). Why did bank lending rates diverge from policy rates after the financial crisis? Bank for International Settlements, Working Paper No 486. 